\title{
Struktur dan Komposisi Vegetasi pada Suksesi di Muara Sungai Unda, Kabupaten Klungkung, Bali
}

\author{
I Made Saka Wijaya ${ }^{1,3)^{*}}$, Gede Surya Indrawan ${ }^{2,3)}$, Putu Angga Wiradana ${ }^{4)}$, \\ I Made Sara Wijana ${ }^{1,3)}$, Abd. Rahman As-syakur, ${ }^{2,3)}$, \\ Adi Ariyanto Wibisono ${ }^{1)}$, Viryanando Evan Rahardja ${ }^{1)}$ \\ 1) Program Studi Biologi, Fakultas Matematika dan Ilmu Pengetahuan Alam, Universitas Udayana \\ Jl. Raya Kampus Unud Jimbaran, Kuta Selatan, Badung - Bali 80361 - Indonesia \\ ${ }^{2)}$ Program Studi Ilmu Kelautan, Fakultas Kelautan dan Perikanan, Universitas Udayana \\ Jl. Raya Kampus Unud Jimbaran, Kuta Selatan, Badung - Bali 80361 - Indonesia \\ 3) Pusat Penelitian Lingkungan Hidup, Universitas Udayana \\ Jl. PB Sudirman, Denpasar Barat, Denpasar - Bali 80234 - Indonesia \\ 4) Program Studi Biologi, Fakultas Ilmu Kesehatan, Sains, dan Teknologi, Universitas Dhyana Pura \\ Jl. Raya Padangluwih, Dalung, Kuta Utara, Badung - Bali 80361 - Indonesia \\ *) Corresponding author: sakawijaya@unud.ac.id
}

\begin{abstract}
ABSTRAK
Letusan Gunung Agung pada tahun 1963 memberikan dampak ekologis di sekitar muara Sungai Unda, Kabupaten Klungkung, Bali. Lahar yang mengalir melalui sungai tersebut menyebabkan terjadinya suksesi primer akibat tutupan pasir dan batu. Selama 57 tahun, muara Sungai Unda tidak hanya mengalami suksesi alam, tetapi juga mengalami suksesi antropogenik melalui pemanfaatan sebagai tambang pasir, lahan pastura, dan permukiman sementara. Penelitian ini bertujuan untuk mempelajari struktur dan komposisi vegetasi pada suksesi di muara Sungai Unda. Penentuan struktur vegetasi dilakukan pada 8 stasiun penelitian dengan menggunakan metode plot dengan jumlah 24 plot pohon $(20 \times 20 \mathrm{~m})$ dan 48 plot vegetasi lantai $(1 \times 1 \mathrm{~m})$. Data dianalisis menggunakan parameter ekologis seperti densitas, densitas relatif, frekuensi, frekuensi relatif, dominansi, dominansi relatif, dan nilai penting, serta dilengkapi dengan indeks keragaman Shannon-Weiner $\left(\mathrm{H}^{\prime}\right)$, indeks dominansi $(\mathrm{C})$, dan indeks keseragaman (E). Hasil penelitian menunjukkan bahwa semak dan rumput merupakan bentuk hidup yang paling menentukan struktur vegetasi di Muara Sungai Unda. Beberapa spesies penyusun vegetasi tersebut merupakan tumbuhan invasif seperti yang harus dikontrol populasinya adalah Typha angustifolia, Ipomoea carnea, Chromolaena odorata, Lantana camara, dan Vachellia farnesiana. Berdasarkan indeks yang digunakan, keanekaragaman vegetasi termasuk dalam kategori tinggi, tanpa ada jenis yang mendominasi, dengan persebaran yang merata.
\end{abstract}

Kata kunci: Gunung Agung; spesies invasive; suksesi antropogenik; vegetasi suksesi

\section{Structure and Composition of Successional Vegetation in Unda River, Klungkung Regency, Bali}

\begin{abstract}
Mount Agung eruption in 1963 caused major ecological impact around Unda River, Klungkung Regency, Bali. The volcanic mudflow that surpass the Unda River watershed initiate the primary succession in those areas. This research aimed to study the structure and composition of successional vegetation in Unda River. Twenty-four tree plots $(20 \times 20 \mathrm{~m})$ and 48 understorey plots $(1 \times 1 \mathrm{~m})$ derived from 8 research stations were used to determine the structure of vegetation. The data analyzed by ecological parameters, such as density, relative density, frequency, relative frequency, dominancy, relative dominancy, and importance value, then completed with ShannonWeiner diversity index $\left(\mathrm{H}^{\prime}\right)$, dominancy index $(\mathrm{C})$, and evenness index $(\mathrm{E})$. The results shown that the vegetation structure in Unda River determined by two major growth form: shrubs and grasses. Some notable invasive species that should be controlled are Typha angustifolia, Ipomoea carnea, Chromolaena odorata, Lantana camara, and Vachellia farnesiana. Based on the three indexes, the
\end{abstract}


vegetation diversity was categorized as high diversity, without any species domination, and the distribution of the species are uniform

Keywords: Anthropogenic succession; invasive species; Mount Agung; successional vegetation

(Article History: Received 06-01-2021; Accepted 25-03-2021; Published 28-03-2021)

\section{PENDAHULUAN}

Gunung Agung merupakan gunung berapi tertinggi yang ada di Bali. Gunung ini sudah meletus beberapa kali sejak tahun 1808 -2018 , namun letusan yang paling berdampak terhadap kehidupan di Bali adalah letusan pada tahun 1963 yang menghanguskan hampir seluruh tumbuhan di kawasan Pura Besakih (Whitten et al., 1996). Pada periode ini, lahar mengalir di berbagai aliran sungai sekaligus mengendapkan pasir dan bebatuan sampai ke muara. Salah satu daerah terdampak adalah di muara di kawasan Sungai Unda, Kabupaten Klungkung. Setelah letusan tersebut, muara ini dikenal sebagai daerah tambang/galian pasir. Daerah tambang dapat mengubah lingkungan disekitarnya melalui perubahan interaksi social-ekonomi masyarakat sekitarnya (Githiria \& Onifade, 2020). Dalam pandangan ekologi, adanya peristiwa gunung meletus dengan lahar yang membanjiri daerah aliran sungai akan mengarah pada peristiwa suksesi.

Suksesi merupakan proses ekologis yang menunjukkan terjadinya perubahan struktur komunitas berdasarkan waktu untuk mencapai komunitas klimaks. Dalam setiap suksesi, akan terjadi dinamika yang diakibatkan oleh interaksi antara spesies dengan lingkungannya (Nylén \& Luoto, 2015; Afrianto et al., 2016), sehingga setiap tahapannya dapat tersusun oleh tipe vegetasi dengan spesies tumbuhan yang berbeda (Thompson et al., 2013). Spesies tumbuhan yang melakukan kolonisasi pada tahap awal suksesi secara tidak langsung akan mempengaruhi komposisi tanah melalui pemanfaatan dan pengembalian karbon dan nitrogen di tanah (Afrianto et al., 2016). Kondisi tersebut akan membentuk karakteristik edafik yang baru dan bervariasi, yang selanjutnya akan diikuti oleh kolonisasi berbagai spesies tumbuhan lain (Prach \& Řehounková, 2006; Windusari et al., 2011; Prach et al., 2014). Tahap awal suksesi ditandai dengan tingginya gangguan ekologis, rendahnya produktivitas dan rendahnya keragaman jenis tumbuhan, sedangkan saat suksesi telah berlangsung lama, maka akan terjadi penurunan gangguan ekologis, peningkatan produktivitas, dan peningkatan keragaman jenis tumbuhan (Isermann, 2011; Nylén \& Luoto, 2015). Peningkatan variasi jenis tumbuhan akan diikuti dengan peningkatan jenis hewan, yang secara simultan akan mempercepat terbentuknya komunitas klimaks.

Suksesi dapat berlangsung dalam berbagai tingkatan dengan kecepatan yang berbeda-beda. Whitten et al. (1996) menyatakan bahwa satu tahun pasca letusan Gunung Agung, jumlah jenis tumbuhan di kawasan Pura Besakih bertambah dari 3 jenis menjadi 83 jenis. Prach et al. (2014) menyatakan bahwa diperlukan waktu rata-rata 20 tahun untuk membentuk vegetasi yang stabil di area suksesi. Faktor lingkungan seperti jenis vegetasi yang berada di sekitar area suksesi, iklim, kelembaban tanah, kandungan Nitrogen, dan tekstur tanah menjadi faktor yang paling berpengaruh dalam keberhasilan terjadinya suksesi (Prach \& Řehounková, 2006). Pada daerah yang mengalami berbagai cekaman lingkungan, kecepatan dan keberhasilan suksesi akan semakin lambat, seperti pada daerah pantai atau gumuk pasir. Daerah pantai atau gumuk pasir mengalami cekaman berupa suhu tinggi, nutrient yang rendah, kecepatan angin yang tinggi, dan dinamika pasir (Pegman \& Rapson, 2005; Çakan et al., 2011; Isermann, 2011). Pada daerah tersebut, tahapan suksesi akan dimulai dari spesies spesifik gumuk pasir (sand dune specialist), semak (mid-seral shrubs), sampai akhirnya komunitas penyusun hutan pantai (coastal forest) (Pegman \& Rapson, 2005).

Muara Sungai Unda merupakan hutan pantai yang banyak dimanfaatkan oleh penduduk sebagai ladang pengembalaan ternak sapi dan kambing (pastura), rekreasi memancing, serta dijadikan permukiman sementara, terutama di daerah hilir atau pantai. Aksesibilitas masyarakat dapat mempengaruhi stabilitas pemulihan ekosistem (Klára et al., 2018) dan cenderung mengarahkan seleksi pada jenis tumbuhan budidaya (Çakan et al., 2011; Hidayat, 2014). 
Penelitian komposisi vegetasi di muara Sungai Unda akan menunjukkan kondisi ekosistem pada proses suksesi di area tambang pasir. Maka dari itu, penelitian ini bertujuan untuk mempelajari struktur dan komposisi vegetasi di muara Sungai Unda, Kabupaten Klungkung, Bali.

\section{METODE PENELITIAN}

\section{a) Waktu dan Tempat Penelitian}

Penelitian dilakukan di muara Sungai Unda, Kabupaten Klungkung, pada bulan Juli sampai September 2020. Untuk mempelajari komposisi vegetasi, area penelitian dibagi menjadi 8 stasiun (Gambar 1). Setiap stasiun terdiri dari 3 titik sampling untuk vegetasi atas (upperstorey) dan 6 titik sampling untuk vegetasi lantai (understorey).

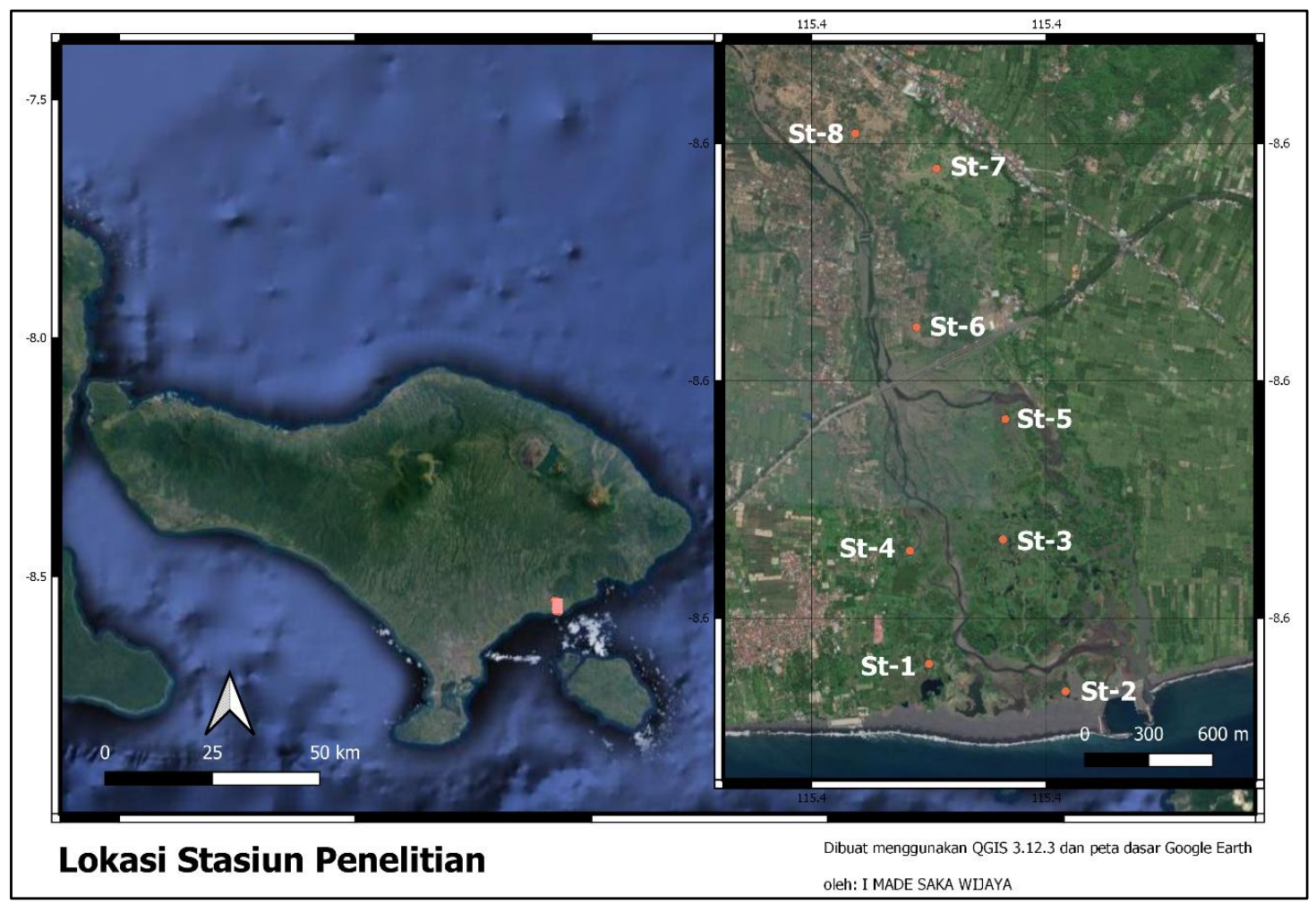

Gambar 1. Lokasi dan stasiun penelitian di Sungai Unda, Klungkung

Keterangan: St-1=Stasiun 1; St-2=Stasiun 2; St-3=Stasiun 3; St-4=Stasiun 4; St-5=Stasiun 5; St-6=Stasiun 6; St-7=Stasiun 7; St-8=Stasiun 8

\section{b) Metode Pengumpulan Data}

\section{Komposisi vegetasi atas (upperstorey)}

Penentuan vegetasi atas menggunakan metode plot dengan ukuran 20 × $20 \mathrm{~m}$. Setiap stasiun ditentukan 3 titik sampling secara acak, sehingga diperoleh 24 plot pengamatan. Pada setiap plot ditandai lokasinya menggunakan GPS [Garmin csx64s]. Parameter yang diambil adalah jumlah pohon, keliling batang tiap pohon, jumlah anak pohon, keliling batang anak pohon, dan jumlah semai, semak, herba, dan paku yang memiliki tinggi $>1,5 \mathrm{~m}$. Suatu tumbuhan digolongkan sebagai pohon apabila keliling batangnya $>31,4 \mathrm{~cm}$, digolongkan anak pohon bila keliling batangnya $6,28-31,4 \mathrm{~cm}$, dan termasuk semai bila keliling batangnya $<6,28$ $\mathrm{cm}$. Setiap data yang diperoleh kemudian ditabulasi untuk dianalisis. Bila terdapat jenis yang belum diketahui, maka sampel diambil dan dijadikan spesimen awetan untuk diidentifikasi lebih lanjut.

\section{Komposisi vegetasi lantai (understorey)}

Pengambilan data vegetasi lantai menggunakan plot berukuran $1 \times 1 \mathrm{~m}$. Pada 
setiap stasiun ditentukan 6 plot pengamatan, sehingga diperoleh 48 plot untuk pengamatan vegetasi lantai. Parameter yang diamati adalah jumlah individu semai, semak, herba, paku, rumput, dan liana dengan tinggi $<1,5 \mathrm{~m}$. Setiap data yang diperoleh kemudian ditabulasi untuk dianalisis. Bila terdapat jenis yang belum diketahui, maka sampel diambil dan dijadikan spesimen awetan untuk diidentifikasi lebih lanjut.

\section{Identifikasi jenis tumbuhan}

Identifikasi jenis tumbuhan dilakukan secara kualitatif dengan membandingkan karakter tumbuhan dengan berbagai pustaka, seperti Flora of Java vol. I, II, dan III (Backer \& van den Brink, 1963; Backer \& van den Brink, 1965; Backer \& van den Brink, 1968), Partomihardjo et al. (2014) dan Suarna et al. (2019).

\section{c) Metode Analisis Data}

Pada penentuan komposisi vegetasi, data yang diperoleh ditabulasi dan dihitung parameter vegetasi yang terdiri dari Densitas, Densitas Relatif, Frekuensi, Frekuensi Relatif, Dominansi, Dominansi Relatif, dan Nilai Penting. Dominansi dan Dominansi Relatif hanya diukur pada bentuk tumbuh pohon dan anak pohon. Pada setiap vegetasi (vegetasi atas dan vegetasi lantai) juga dihitung Indeks Diversitas Shannon-Weiner (H'), Indeks Dominansi (C), dan Indeks Keseragaman (E). Rumus yang digunakan dalam analisis komposisi vegetasi adalah sebagai berikut:

$$
\begin{aligned}
& \text { Densitas (individu/m2) } \\
& =\frac{\text { Jumlah individu suatu spesies }}{\text { Luas area }} \\
& \text { Densitas Relatif }(\%) \\
& =\frac{\text { Densitas suatu spesies }}{\text { Densitas keseluruhan spesies }} \times 100 \%
\end{aligned}
$$

Frekuensi $=\frac{\text { Jumlah kehadiran suatu spesies }}{\text { Jumlah keseluruhan titik sampling }}$

Frekuensi Relatif (\%)

$=\frac{\text { Frekuensi suatu spesies }}{\text { Frekuensi keseluruhan spesies }} \times 100 \%$

Luas Basal Area $(m 2)=\frac{(\text { Keliling batang })^{2}}{4 \pi}$
Dominansi $(m 2)$

$=$ Rata

- rata LBA suatu spesies $x$ Densitas suatu spesies

Dominansi Relatif (\%)

$=\frac{\text { Dominansi suatu spesies }}{\text { Dominansi keseluruhan spesies }} \times 100 \%$

Nilai Penting $=$ Densitas Relatif

+ Frekuensi Relatif

+ Dominansi Relatif

Indeks Diversitas Shannon - Weiner $\left(H^{\prime}\right)$

$$
=-\sum_{i=1}^{s}\left(\frac{n i}{N}\right)\left(\ln \frac{n i}{N}\right)
$$

Keterangan:

ni $=$ indeks nilai penting suatu spesies

$\mathrm{N}=$ indeks nilai penting keseluruhan

$\mathrm{H}^{\prime}=$ indeks diversitas Shannon-Weiner

Ketentuan:

$\mathrm{H}^{\prime}<1=$ diversitas rendah

$1<\mathrm{H}^{\prime}<3=$ diversitas sedang

$\mathrm{H}^{\prime}>3=$ diversitas tinggi

Indeks Dominansi $(C)=\sum_{i=1}^{s}\left(\frac{n i}{N}\right)^{2}$

Keterangan:

ni $=$ indeks nilai penting suatu spesies

$\mathrm{N}=$ indeks nilai penting keseluruhan

$\mathrm{C}=$ indeks dominansi

Ketentuan:

$\mathrm{C}<0,5=$ tidak terdapat jenis yang

mendominasi

$\mathrm{C}>0,5=$ terdapat jenis yang mendominasi

Indeks Keseragaman $(E)=\frac{H^{\prime}}{\ln (\text { jumlah spesies })}$

Keterangan:

$\mathrm{H}^{\prime}=$ indeks diversitas Shannon-Weiner

$\mathrm{E}=$ indeks keseragaman

Ketentuan:

$\mathrm{E}<0,5=$ komposisi vegetasi tidak merata

$\mathrm{E}>0,5=$ komposisi vegetasi merata/seragam

\section{HASIL DAN PEMBAHASAN}

\section{a) Vegetasi Atas (Upperstory)}

Vegetasi atas (upperstorey) di muara Sungai Unda terdiri dari 5 bentuk hidup (growthform) utama, yaitu pohon, anak pohon, semak, paku, dan herba. Terdapat 20 spesies pohon yang dijumpai, 16 spesies anak pohon, 15 spesies semak, 1 spesies paku, dan 4 spesies herba (Gambar 2). Satu-satunya jenis paku yang termasuk dalam vegetasi ini adalah paku laut (Acrosthicum aureum: Pteridaceae). 
Paku laut merupakan jenis tumbuhan yang umum dijumpai di daerah pesisir sampai mangrove, terutama yang mengalami kerusakan lingkungan (Whitten et al., 1996). Keberadaan paku laut yang tinggi dan besar di Muara Sungai Unda menunjukkan rangkaian tahapan suksesi (sere/serial) sudah berjalan sejak lama, namun hingga saat ini belum sampai pada komunitas klimaks.

Komunitas klimaks dicirikan oleh stabilitas vegetasi dengan keberhasilan regenerasi spesies (terutama pohon) yang tinggi. Hal ini dapat dilihat dari komposisi vegetasi tiap bentuk hidup melalui parameter vegetasi, seperti Indeks Nilai Penting (INP). INP tertinggi di muara ini adalah bentuk hidup semak dengan nilai $116,15 \%$, sedangkan pohon sebesar $109,98 \%$, herba $39,33 \%$, anak pohon $29,42 \%$, dan paku 5,12\% (Gambar 3). Bila dibandingkan parameter densitas relatif (DR) dan frekuensi relatif (FR) pada setiap bentuk hidup, maka bentuk hidup semak memiliki nilai DR dan FR yang jauh lebih besar dibandingkan dengan bentuk hidup lainnya. Tahapan suksesi dengan dominasi semak berukuran tinggi menunjukkan fase pra-hutan (pre-forest stage), yang secara perlahan akan diikuti oleh peningkatan pohon pionir (Walentowski et al., 2018). Keberadaan semak dalam fase ini sangat penting karena berperan dalam melindungi semai dari cekaman lingkungan (Moradipour et al., 2020).

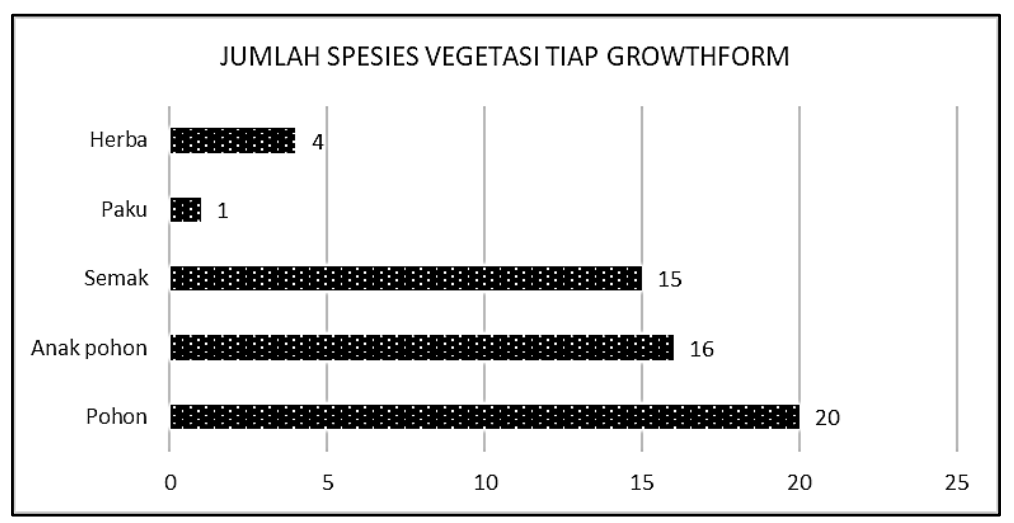

Gambar 2. Jumlah spesies vegetasi untuk setiap bentuk hidup (growthform) pada plot 20x20 m di Sungai Unda, Klungkung, Bali

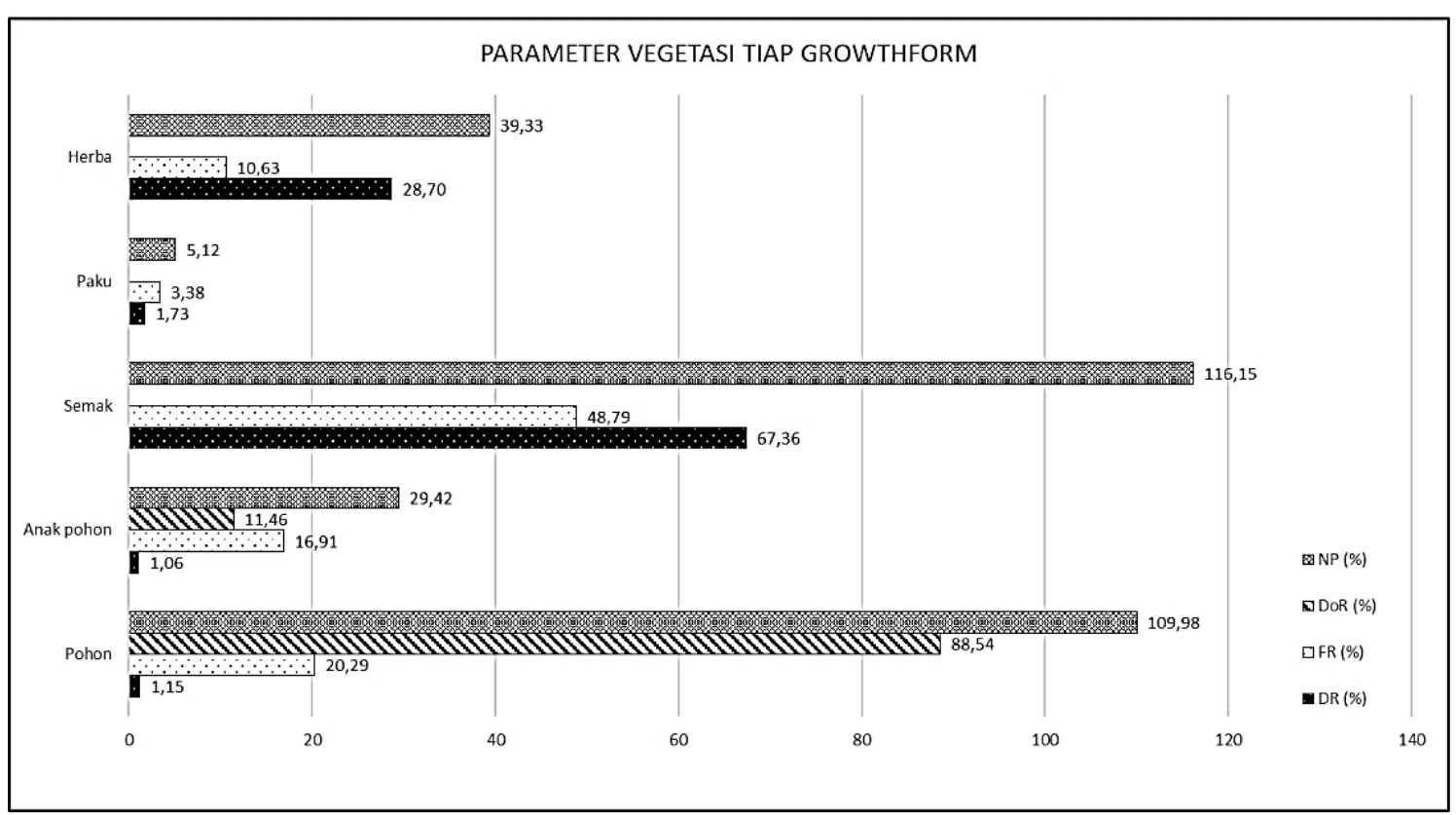

Gambar 3. Parameter vegetasi untuk setiap bentuk hidup (growthform) pada plot 20x20 m di Sungai Unda, Klungkung, Bali 
Di Muara Sungai Unda, jumlah spesies anak pohon yang dijumpai lebih sedikit dari jumlah spesies pohon menunjukkan bahwa terdapat gangguan dalam regenerasi tumbuhan. Kasus yang sama juga terjadi pada populasi cemara laut (Casuarina equisetifolia) yang terdapat pada tiga kawasan konservasi di Bengkulu, yang didominasi oleh fase pohon daripada anak pohon (Farma et al., 2019). Gangguan regenerasi dapat disebabkan oleh kompetisi dengan tumbuhan lain, kondisi lingkungan abiotik yang tercekam, maupun pemanfaatan sebagai pastura. Spesies tumbuhan akan sulit berkembang bila berkompetisi dengan tumbuhan invasif yang berukuran besar, seperti ekor kucing (Typha angustifolia: Typhaceae), kangkung pagar (Ipomoea carnea: Convolvulaceae), kirinyuh (Chromolaena odorata: Asteraceae), dan tembelekan (Lantana camara: Verbenaceae). Tumbuhan tersebut dijumpai sangat melimpah di sekitar kawasan penelitian dengan nilai INP sebesar 12,18\% - 32,12\% (Lampiran 1). Keberadaan spesies invasif dapat menyebabkan efek berkelanjutan. Dominasi spesies invasif dapat menurunkan spesies tumbuhan lokal yang menjadi sumber pakan berbagai jenis hewan, sehingga diperlukan monitoring persebaran tumbuhan invasif (Febriana et al., 2020).

Kondisi lingkungan dengan cekaman yang ekstrem juga mempengaruhi proses fisiologis tumbuhan, sehingga cenderung menghambat pertumbuhan dan perkembangannya. Beberapa area dengan cekaman ekstrem di kawasan penelitian adalah area yang tergenang seperti rawa (marsh) dan gumuk pasir (sand dune). Pada area tergenang, jenis khas yang umum dijumpai adalah ekor kucing (T. angustifolia), sedangkan pada gumuk pasir yang panas banyak dijumpai widuri (Calotropis gigantea: Asclepiadaceae) dan akasia duri (Vachellia farnesiana: Fabaceae). Bentuk hidup semak memiliki toleransi fisiologis yang cenderung besar, sehingga mampu melakukan kolonisasi di area dengan cekaman ekstrem tersebut. Hal tersebut berimplikasi pada tingginya DR dan FR semak tersebut. Densitas yang tinggi menunjukkan keberhasilan reproduksi, sedangkan frekuensi yang tinggi menunjukkan efektivitas persebaran. Dengan nilai DR $67,36 \%$, ini menunjukkan bahwa densitas semak lebih dari setengah densitas vegetasi keseluruhan. Dari nilai DR tersebut, 22,46\% adalah kirinyuh $(C$. odorata). Kirinyuh $(C$. odorata) juga memiliki nilai FR tertinggi $(9,66 \%)$, nilai yang sama dengan widuri $(C$. gigantea).

Pemanfaatan sebagai pastura termasuk degradasi hutan karena menurunkan kapasitas dan potensi hutan (Thompson et al., 2013). Pemanfaatan pastura juga dapat menurunkan jumlah spesies pohon dan anak pohon, karena semai sulit untuk tumbuh akibat rendahnya lapisan serasah, dimakan hewan ternak, maupun terinjak. Lahan pastura memiliki lapisan organik (serasah) yang lebih tipis dibandingkan dengan hutan (Walentowski et al., 2018), sehingga kandungan nutrien pada tanah lebih rendah. Hewan ternak yang umum dijumpai di kawasan tersebut adalah sapi dan kambing. Ciri khas dari pastura tersebut umumnya berupa padang rumput yang luas dengan sedikit pohon. Salah satu jenis pohon yang banyak dijumpai di kawasan pastura adalah dlundung (Erythrina variegata: Fabaceae). Pohon tersebut juga memiliki DR tertinggi dibandingkan dengan jenis pohon lainnya $(0,20 \%)$.

Tabel 1. Indeks diversitas Shannon-Weiner $\left(\mathrm{H}^{\prime}\right)$, Dominansi (C), dan Keseragaman (E) pada vegetasi upperstorey di Sungai Unda, Klungkung, Bali

\begin{tabular}{llccc}
\hline No & $\begin{array}{c}\text { Bentuk Hidup } \\
(\text { Growthform })\end{array}$ & H'$^{\prime}$ & $\mathbf{C}$ & $\mathbf{E}$ \\
\hline 1 & Pohon & 1,33 & 0,0121 & 0,33 \\
2 & Anak pohon & 0,46 & 0,0012 & 0,12 \\
3 & Semak & 1,17 & 0,0248 & 0,29 \\
4 & Paku & 0,07 & 0,0003 & 0,02 \\
5 & Herba & 0,38 & 0,0078 & 0,09 \\
& TOTAL & 3,42 & 0,0462 & 0,85 \\
\hline
\end{tabular}

Untuk mempelajari komposisi vegetasi, penggunaan indeks dapat membantu dalam memberikan gambaran umumnya. Nilai Indeks Diversitas Shannon-Weiner (H') di Muara Sungai Unda sebesar 3,42, Indeks Dominansi (C) sebesar 0,0462, dan Indeks Keseragaman (E) sebesar 0,85\% (Tabel 1). Berdasarkan Indeks Diversitas (H') dengan nilai $3,42 \quad(>3), \quad$ diversitas atau keanekaragaman vegetasi termasuk tinggi. Nilai H' yang tinggi adalah hal yang umum dijumpai di daerah tropis. Indeks Dominansi vegetasi memiliki nilai yang sangat rendah, 
yaitu 0,0462 dari rentang indeks antara $0-1$. Dengan nilai mendekati $0(\mathrm{C}<0,5)$, ini menunjukkan bahwa di lokasi penelitian tidak terdapat jenis tumbuhan yang mendominasi. Komposisi vegetasi juga cenderung merata bila ditinjau dari Indeks Keseragaman (E) yang bernilai 0.85 (dari rentang indeks antara $0-1$ ). Semakin mendekati nilai 1 , komposisi vegetasi dinyatakan semakin merata.

\section{b) Vegetasi Lantai (Understorey)}

Vegetasi lantai akan mendominasi pada tahap awal suksesi dan mempengaruhi proses pembentukan tanah melalui pemanfaatan sumber daya yang tersedia (Afrianto et al., 2016). Vegetasi lantai di Muara Sungai Unda tersusun atas 6 bentuk hidup, yaitu semai (6 jenis), semak (22 jenis), herba (40 jenis), rumput (31 jenis), paku ( 2 jenis), dan liana (4 jenis) seperti pada Gambar 4. Herba merupakan bentuk hidup dengan jenis terbanyak, namun memiliki parameter vegetasi yang lebih sedikit dibandingkan rumput. Parameter vegetasi pada vegetasi lantai seperti Densitas Relatif (DR), Frekuensi Relatif (FR), dan Indeks Nilai Penting (INP) ditunjukkan oleh Gambar 5. Secara lebih terperinci, parameter vegetasi terdapat pada Lampiran 2.
Rumput merupakan bentuk hidup dengan INP tertinggi, yaitu 109,98\%, sedangkan herba sebesar 48,78\%, semak $34,48 \%$, liana $3,24 \%$, semai $2,71 \%$, dan paku $0,91 \%$. Perbandingan DR antara rumput dan herba sangat berbeda, yaitu $74,72 \%$ pada rumput dan $12,52 \%$. Secara umum, tingginya densitas rumput disebabkan oleh dua hal, yaitu mekanisme alami kolonisasi rumput dan seleksi melalui pastura.

Mekanisme kolonisasi rumput yang dimaksud adalah tendensi dari rumput (Poaceae) dan teki (Cyperaceae) dalam menerapkan strategi $\mathrm{R}$ (ruderal) di lingkungan yang baru. Strategi $R$ akan mengoptimalkan sumberdaya yang ada untuk meningkatkan laju reproduksi, sehingga densitas akan meningkat dengan cepat (Radford, 2013). Pada bentuk hidup rumput, strategi ini dilakukan melalui siklus hidup yang pendek, menghasilkan biji yang banyak, persebaran biji melalui angin untuk menjangkau area lebih luas, serta memiliki reproduksi vegetatif yang efektif untuk meningkatkan penutupan lahan. Semakin luas tutupan lahan, maka probabilitas tumbuhan lain untuk berkecambah akan semakin kecil. Dalam siklus suksesi, rumput dan teki merupakan tumbuhan terofit yang umum dijumpai di daerah pantai (Çakan et al., 2011).

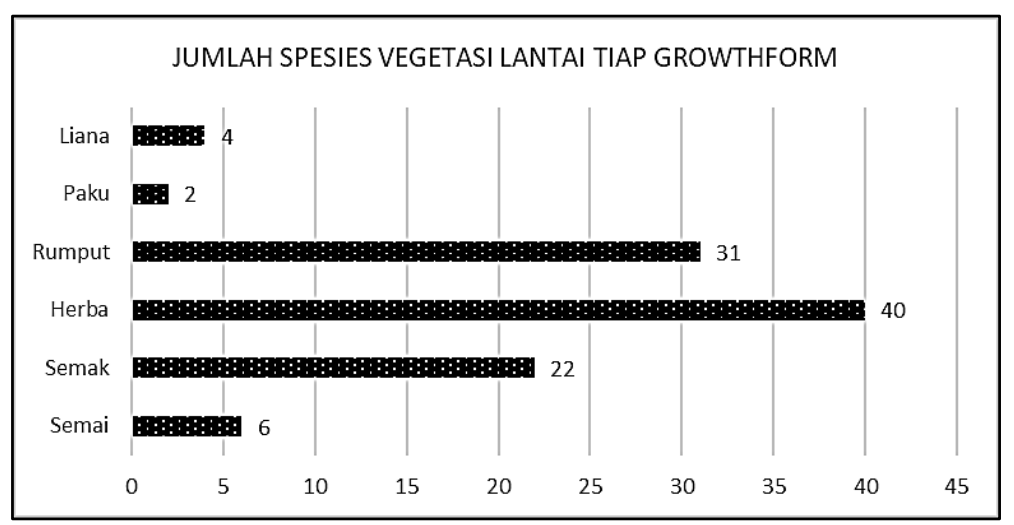

Gambar 4. Jumlah spesies vegetasi lantai untuk setiap bentuk hidup (growthform) pada plot 1x1 $\mathrm{m}$ di Sungai Unda, Klungkung, Bali 


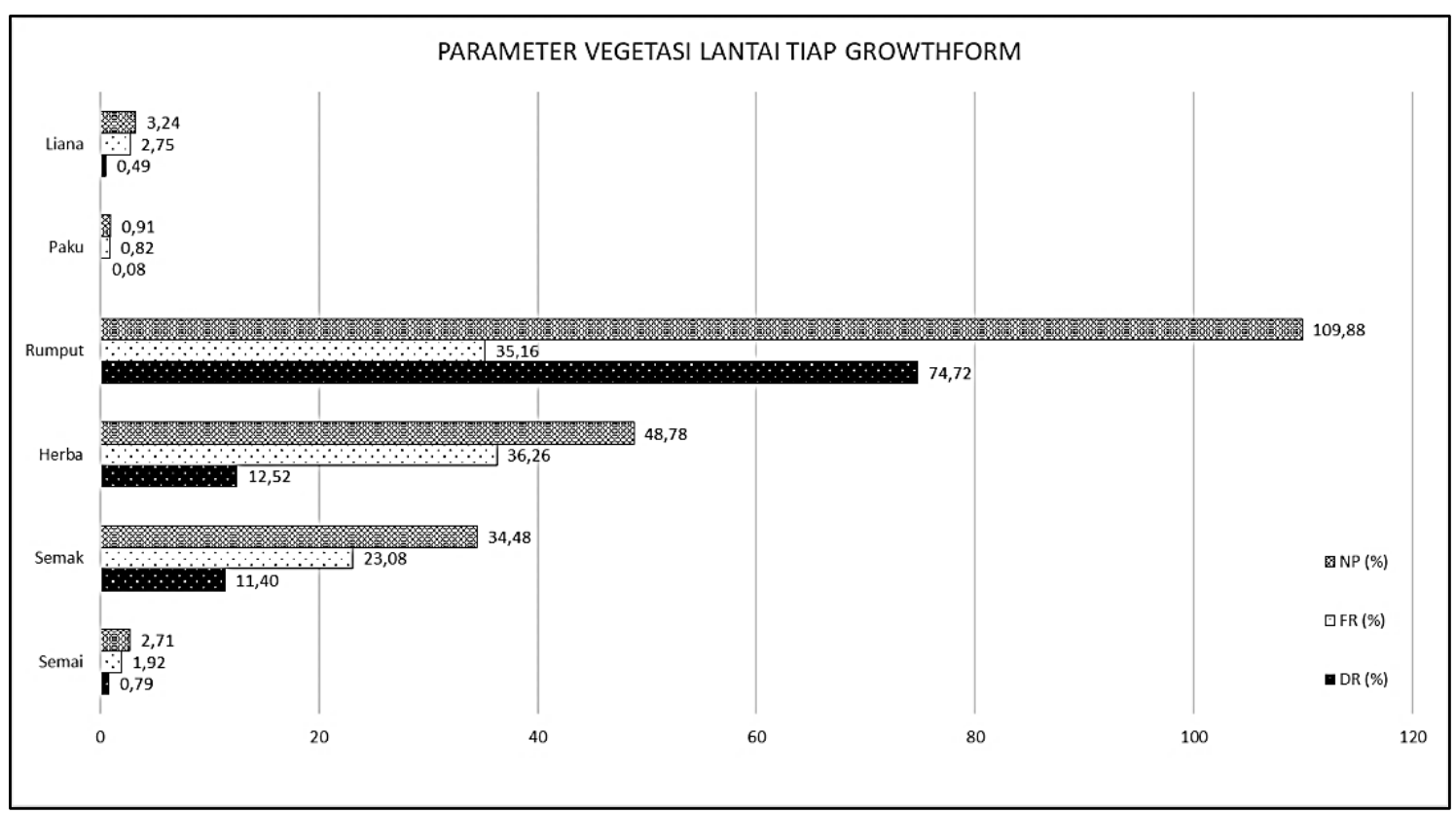

Gambar 5. Parameter vegetasi lantai untuk setiap bentuk hidup (growthform) pada plot 20x20 $m$ di Sungai Unda, Klungkung, Bali

Pada seleksi akibat penggunaan lahan sebagai pastura, tingginya densitas rumput karena kepentingannya sebagai pakan ternak (Moradipour et al., 2020). Dalam pandangan segitiga C-S-R yg dikemukakan oleh Grime, aktivitas penggembalaan merupakan kategori gangguan (disturbance) yang menguntungkan tumbuhan berstrategi R (Radford, 2013). Padang lepas (Zoysia matrella: Poaceae) merupakan jenis rumput dengan DR tertinggi $(27,14 \%)$ dan INP tertinggi $(31,81 \%)$. Padang lepas juga termasuk jenis rumput pakan ternak yang baik dan banyak dimanfaatkan oleh masyarakat Bali (Suarna et al., 2019). Seleksi sebagai pastura juga mempengaruhi densitas tumbuhan lain, terutama semai dan semak. Semai dan semak yang dapat dikonsumsi oleh ternak sangat sedikit dijumpai di lahan pastura, sedangkan jenis yang tidak disukai ternak umumnya melimpah, seperti widuri $(C$. gigantea) yang bergetah dan akasia duri ( $V$. farnesiana). Secara umum, pemanfaatan hutan sebagai pastura akan menurunkan produktivitas ekosistem karena menimbulkan lebih banyak lahan terbuka (Walentowski et al., 2018).
Tabel 2. Indeks diversitas Shannon-Weiner (H'), Dominansi (C), dan Keseragaman (E) pada vegetasi lantai (understorey) di Sungai Unda, Klungkung, Bali

\begin{tabular}{|c|c|c|c|c|}
\hline No & $\begin{array}{c}\text { Bentuk } \\
\text { Hidup } \\
\text { (Growthform) }\end{array}$ & $\mathbf{H}^{\prime}$ & C & $\mathbf{E}$ \\
\hline 1 & Semai & 0,08 & 0,000049 & 0,02 \\
\hline 2 & Semak & 0,75 & 0,003625 & 0,16 \\
\hline 3 & Herba & 1,16 & 0,002812 & 0,25 \\
\hline 4 & Rumput & 1,81 & 0,000012 & 0,39 \\
\hline 5 & Paku & 0,03 & 0,000012 & 0,01 \\
\hline 6 & Liana & 0,09 & 0,000077 & 0,02 \\
\hline TO' & $\mathrm{AL}$ & 3,91 & 0,006587 & 0,84 \\
\hline $\begin{array}{l}\text { ditur } \\
\text { Dive } \\
\text { kean } \\
\text { tings } \\
\text { Rum } \\
\text { deng } \\
\text { paku } \\
\text { keen } \\
\text { spes } \\
\text { Dom } \\
\text { sang } \\
0 \text {, ya } \\
\text { spes }\end{array}$ & $\begin{array}{l}\text { Indeks yan } \\
\text { etahui komp } \\
\text { jukkan oleh Tab } \\
\text { sitas Sha } \\
\text { karagaman ve } \\
\text { (dengan nilai } 3 \\
\text { put dan herba r } \\
\text { in keanekaragar } \\
\text { dan liana te } \\
\text { m bentuk hidup } \\
\text { es yang mendom } \\
\text { nansi (C). Nila } \\
\text { t rendah }(0,006 \\
\text { g menunjukkar } \\
\text { es. Berdasarka }\end{array}$ & $\begin{array}{l}\text { di } \\
\text { sisi } \\
\text { el 2. B } \\
\text { non- } \\
\text { getasi } \\
\text { 91) } \mathrm{k} \\
\text { erupa } \\
\text { han te } \\
\text { masul } \\
\text { yang } \\
\text { inasi } \\
\text { C pa } \\
587), \\
\text { tidak } \\
\text { Ind }\end{array}$ & $\begin{array}{l}\text { gunakan } \\
\text { vegetasi } \\
\text { erdasarkan } \\
\text { Jeiner } \\
\text { lantai te } \\
\text { rena nilain } \\
\text { kan bentuk } \\
\text { tinggi, sed } \\
\text { terendah } \\
\text { ijumpai, tic } \\
\text { erdasarkan } \\
\text { da vegetas } \\
\text { ahkan me } \\
\text { adanya don } \\
\text { ks Kesera }\end{array}$ & $\begin{array}{r}\text { untuk } \\
\text { lantai } \\
\text { Indeks } \\
\left(\mathrm{H}^{\prime}\right) \text {, } \\
\text { masuk } \\
\text { ya }>3 . \\
\text { hidup } \\
\text { angkan } \\
\text { Dari } \\
\text { lak ada } \\
\text { Indeks } \\
\text { lantai } \\
\text { dekati } \\
\text { inansi } \\
\text { gaman }\end{array}$ \\
\hline
\end{tabular}


(E), komposisi vegetasi lantai termasuk merata atau seragam, karena nilai indeks yang diperoleh $(0,84)$ lebih tinggi dari 0,5 .

\section{KESIMPULAN}

Pada vegetasi atas (upperstorey) di Muara Sungai Unda, semak merupakan bentuk hidup dengan INP tertinggi, meskipun bentuk hidup pohon memiliki jumlah spesies terbanyak. Berdasarkan indeks yang digunakan, keanekaragaman vegetasi atas termasuk tinggi, tanpa ada jenis yang mendominasi, dengan persebaran dan merata. Jenis yang perlu diperhatikan adalah keberadaan dan persebaran spesies invasif seperti ekor kucing (T. angustifolia), kangkung pagar (I. carnea), kirinyuh ( $C$. odorata), tembelekan (L. camara), dan akasia duri (Vachellia farnesiana). Pada vegetasi lantai (understorey), rumput menjadi bentuk hidup dengan INP tertinggi. Dalam kaitannya terhadap suksesi, bentuk hidup rumput sangat adaptif bila ditinjau dari strategi $\mathrm{R}$ dan seleksi penggunaan lahan sebagai pastura. Berdasarkan indeks yang digunakan, keanekaragaman vegetasi lantai termasuk tinggi, tanpa ada jenis yang mendominasi, dengan persebaran dan merata.

\section{UCAPAN TERIMA KASIH}

Terima kasih kepada Pusat Penelitian Lingkungan Hidup (PPLH) Universitas Udayana atas bantuan penelitian di Muara Sungai Unda, Kabupaten Klungkung, Bali.

\section{DAFTAR PUSTAKA}

Afrianto, W.F., Hikmat, A., \& Widyatmoko, D. 2016. Komunitas Floristik Dan Suksesi Vegetasi Setelah Erupsi 2010 Di Gunung Merapi Jawa Tengah. Biologi Indonesia. 12(2): 265-276.

Backer, C.A. \& van den Brink, R.C.B. 1963. Flora of Java (Spermatophytes only) Volume I. Netherlands: N.V.P. Noordhoff-Groningen.

Backer, C.A. \& van den Brink, R.C.B. 1965. Flora of Java (Spermatophytes only) Volume II. Netherlands: N.V.P. Noordhoff-Groningen.
Backer, C.A. \& van den Brink, R.C.B 1968. Flora of Java (Spermatophytes only) Volume III. Netherlands: N.V.P. Noordhoff-Groningen.

Çakan, H., Yilmaz, K.T., Alphan, H. \& Ünlükaplan, Y. 2011. The classification and assessment of vegetation for monitoring coastal sand dune succession: The case of Tuzla in Adana, Turkey. Turk J Botany, 35(6): 697-711. doi:10.3906/bot-1001-300.

Farma, A., Hikmat, A. \& Soekmadi, R. 2019. Struktur dan Komposisi Vegetasi di Habitat Cemara Laut (Casuarina equisetifolia L.) pada Tiga Kawasan Konservasi di Provinsi Bengkulu. JPSL. 9(3): 596-607.

Febriana, I., Kusmana, C. \& Rahmat, U.M. 2020. Komposisi Jenis Tumbuhan dan Analisis Sebaran Langkap (Arenga obtusifolia Mart.) di Taman Nasional Ujung Kulon. JPSL. 10(1): 52-65.

Githiria, J.M. \& Onifade, M. 2020. The impact of mining on sustainable practices and the traditional culture of developing countries. J Environmental Studies and Science. 10(4): 394-410. doi:10.1007/s13412-020-00613-w.

Hidayat, S. 2014. Kondisi Vegetasi Di Hutan Lindung Sesaot, Kabupaten Lombok Barat, Nusa Tenggara Barat, Sebagai Informasi Dasar Pengelolaan Kawasan. $J$ Penelitian Kehutanan Wallacea, 3(2): 97-105.

Isermann, M. 2011. Patterns in species diversity during succession of coastal dunes. J Coastal Research, 27(4): 661671. doi:10.2112/JCOASTRES-D-0900040.1.

Klára, ̌̌., Lencová, K. \& Prach, K. 2018. Spontaneous establishment of woodland during succession in a variety of central European disturbed sites. Ecological Engineering, 111: 94-99.

Moradipour, L., Pourbabaei, H. \& Hatami, A. 2020. Vegetation structure and floristic composition (Case study: Mala Galeh Protected area, Fars Province, Iran). JPSL, 10(3): 533-544. 
Nylén, T. \& Luoto, M. 2015. Primary succession, disturbance and productivity drive complex species richness patterns on land uplift beaches. J Veg Sci., 26: 267-277. doi:10.1111/jvs.12232.

Partomihardjo, T., Arifiani, D., Pratam, B.A. \& Mahyuni, R. 2014. Jenis-jenis Pohon Penting di Hutan Nusa Kambangan. Jakarta: LIPI Press.

Pegman, A.P.M. \& Rapson, G.L. 2005. Plant succession and dune dynamics on actively prograding dunes, Whatipu Beach, northern New Zealand. New Zealand Journal of Botany, 43(1): 223244.

Prach, K. \& Řehounková, K. 2006. Vegetation succession over broad geographical scales: Which factors determine the patterns? Preslia, 78(4): 469-480.

Prach, K., Řehounková, K., Lencová, K., Jírová, A., Konvalinková, P., Mudrák, O., Študent, V., Vaněček, Z., Tichý, L., Petřík, P., Šmilauer, P. \& Pyšek, P. 2014. Vegetation succession in restoration of disturbed sites in Central Europe: The direction of succession and species richness across 19 seres. Applied Vegetation Science, 17: 193-200. doi:10.1111/avsc.12064.

Radford, I.J. 2013. Fluctuating resources, disturbance and plant strategies: Diverse mechanisms underlying plant invasions. $J$ Arid Land., 5(3): 284-297. doi:10.1007/s40333-013-0164-0.
Suarna, I.W., Suryani, N.N. \& Budiasa, K.M. 2019. Biodiversitas Tumbuhan Pakan Ternak. Prasasti, Denpasar.

Thompson, I.D., Guariguata, M.R., Okabe, K., Bahamondez, C., Nasi, R., Heymell, V. \& Sabogal, C. 2013. An Operational Framework for Defining and Monitoring Forest Degradation. Ecology and Society, 18(2): 20.

Walentowski, H., Heinrichs, S., Hohnwald, S., Wiegand, A., Heinen, H., Thren, M., Gamarra O.A., Torres, Sabogal, A.B. \& Zerbe, S. 2018. Vegetation succession on degraded sites in the Pomacochas Basin (Amazonas, N Peru)-Ecological options for forest restoration. Sustainability, $\quad \mathbf{1 0 ( 3 ) :} \quad 1-17$. doi:10.3390/su10030609.

Whitten, T., Soeriaatmadja, R.E. \& Afiff, S.A. 1996. The Ecology of Java and Bali. Periplus Editions (HK) Ltd., Singapore

Windusari, Y., Susanto, R.H., Dahlan, Z. \& Susetyo, W. 2011. Asosiasi Jenis Pada Komunitas Vegetasi Suksesi di Kawasan Pengendapan Tailing Tanggul Ganda di Pertambangan PTFI Papua. J Biota, 16(2): 242-251. 


\section{LAMPIRAN}

\section{Lampiran 1. Data parameter vegetasi upperstorey di Sungai Unda, Klungkung, Bali}

Keterangan:

DR = Densitas Relatif; FR = Frekuensi Relatif; DoR = Dominansi Relatif; INP = Indeks Nilai Penting

\begin{tabular}{|c|c|c|c|c|c|c|c|c|}
\hline No & No & Nama Spesies & Nama Lokal & Suku & $\begin{array}{l}\text { DR } \\
(\%)\end{array}$ & $\begin{array}{l}\text { FR } \\
(\%)\end{array}$ & $\begin{array}{l}\text { DoR } \\
(\%)\end{array}$ & $\begin{array}{l}\text { INP } \\
(\%)\end{array}$ \\
\hline \multicolumn{9}{|c|}{ Growthform Pohon } \\
\hline 1 & 1 & Acacia auriculiformis & Akasia & Fabaceae & 0,15 & 2,90 & 7,63 & 10,68 \\
\hline 2 & 2 & Barringtonia asiatica & Keben & Lecythidaceae & 0,02 & 0,48 & 3,16 & 3,66 \\
\hline 3 & 3 & Calliandra $s p$ & - & Fabaceae & 0,02 & 0,48 & 2,83 & 3,32 \\
\hline 4 & 4 & $\begin{array}{l}\text { Calophyllum } \\
\text { inophyllum }\end{array}$ & Nyamplung & Calophyllaceae & 0,03 & 0,97 & 3,28 & 4,28 \\
\hline 5 & 5 & Delonix regia & Flamboyan & Fabaceae & 0,02 & 0,48 & 4,72 & 5,22 \\
\hline 6 & 6 & Erythrina variegata & Dlundung & Fabaceae & 0,20 & 2,42 & 13,28 & 15,89 \\
\hline 7 & 7 & Ficus hispida & Aa madangan & Moraceae & 0,02 & 0,48 & 0,45 & 0,95 \\
\hline 8 & 8 & Ficus septica & Awar-awar & Moraceae & 0,20 & 1,93 & 10,30 & 12,43 \\
\hline 9 & 9 & Gliricidia sepium & Gamal & Fabaceae & 0,02 & 0,48 & 1,31 & 1,81 \\
\hline 10 & 10 & Gluta renghas & Rengas & Anacardiaceae & 0,02 & 0,48 & 0,51 & 1,01 \\
\hline 11 & 11 & Hibiscus tiliaceus & $\begin{array}{l}\text { Waru, waru } \\
\text { laut }\end{array}$ & Malvaceae & 0,05 & 0,97 & 3,97 & 4,99 \\
\hline 12 & 12 & Lagerstroemia india & Bungur & Lythraceae & 0,02 & 0,48 & 0,28 & 0,78 \\
\hline 13 & 13 & Lannea coromandelica & Kayu santen & Anacardiaceae & 0,15 & 1,93 & 15,31 & 17,40 \\
\hline 14 & 14 & $\begin{array}{l}\text { Leucaena } \\
\text { leucocephala }\end{array}$ & Lamtoro & Fabaceae & 0,08 & 0,97 & 6,68 & 7,72 \\
\hline 15 & 15 & Melochia umbellata & Senu & Malvaceae & 0,02 & 0,48 & 0,82 & 1,32 \\
\hline 16 & 16 & Macaranga tanarius & Mara & Euphorbiaceae & 0,02 & 0,48 & 0,24 & 0,73 \\
\hline 17 & 17 & Muntingia calabura & $\begin{array}{l}\text { Kersen, } \\
\text { singapur }\end{array}$ & Muntingiaceae & 0,06 & 1,45 & 3,66 & 5,17 \\
\hline 18 & 18 & Samanea saman & $\begin{array}{l}\text { Trembesi, } \\
\text { suar }\end{array}$ & Fabaceae & 0,02 & 0,48 & 2,00 & 2,50 \\
\hline 19 & 19 & $\begin{array}{l}\text { Spathodea } \\
\text { campanulata }\end{array}$ & $\begin{array}{l}\text { Spatodea, } \\
\text { kiacret }\end{array}$ & Bignoniaceae & 0,03 & 0,48 & 1,20 & 1,72 \\
\hline 20 & 20 & Terminalia catappa & Ketapang & Combretaceae & 0,06 & 1,45 & 6,89 & 8,40 \\
\hline \multicolumn{5}{|c|}{ SUBTOTAL } & 1,15 & 20,29 & 88,54 & 109,98 \\
\hline \multicolumn{9}{|c|}{ Growthform Anak Pohon } \\
\hline 21 & 1 & Acacia auriculiformis & Akasia & Fabaceae & 0,08 & 1,93 & 0,27 & 2,28 \\
\hline 22 & 2 & Erythrina variegata & Dlundung & Fabaceae & 0,05 & 1,45 & 0,34 & 1,83 \\
\hline 23 & 3 & Ficus hispida & Aa madangan & Moraceae & 0,11 & 0,48 & 1,00 & 1,59 \\
\hline 24 & 4 & Ficus septica & Awar-awar & Moraceae & 0,33 & 4,35 & 1,92 & 6,60 \\
\hline 25 & 5 & Gluta renghas & Rengas & Anacardiaceae & 0,08 & 0,97 & 0,16 & 1,20 \\
\hline 26 & 6 & Gmelina arborea & $\begin{array}{l}\text { Jati putih, } \\
\text { gamelina }\end{array}$ & Lamiaceaea & 0,02 & 0,48 & 0,12 & 0,62 \\
\hline 27 & 7 & Hibiscus tiliaceus & Waru & Malvaceae & 0,02 & 0,48 & 0,01 & 0,51 \\
\hline 28 & 8 & Lagerstroemia india & Bungur & Lythraceae & 0,02 & 0,48 & 0,11 & 0,61 \\
\hline 29 & 9 & Lannea coromandelica & Kayu santen & Anacardiaceae & 0,09 & 1,45 & 0,66 & 2,20 \\
\hline 30 & 10 & $\begin{array}{l}\text { Leucaena } \\
\text { leucocephala }\end{array}$ & Lamtoro & Fabaceae & 0,06 & 0,48 & 5,64 & 6,19 \\
\hline 31 & 11 & Macaranga tanarius & Mara & Euphorbiaceae & 0,02 & 0,48 & 0,19 & 0,69 \\
\hline 32 & 12 & Melochia umbellata & Senu & Malvaceae & 0,02 & 0,48 & 0,08 & 0,58 \\
\hline 33 & 13 & Muntingia calabura & $\begin{array}{l}\text { Singapur, } \\
\text { kersen }\end{array}$ & Muntingiaceae & 0,06 & 0,97 & 0,53 & 1,55 \\
\hline 34 & 14 & Ricinus communis & Jarak & Euphorbiaceae & 0,05 & 0,48 & 0,09 & 0,62 \\
\hline 35 & 15 & Senna alata & $\begin{array}{l}\text { Ketepeng } \\
\text { Cina }\end{array}$ & Fabaceae & 0,03 & 0,97 & 0,10 & 1,09 \\
\hline 36 & 16 & $\begin{array}{l}\text { Spathodea } \\
\text { campanulata }\end{array}$ & $\begin{array}{l}\text { Spatodea, } \\
\text { kiacret }\end{array}$ & Bignoniaceae & 0,06 & 0,97 & 0,23 & 1,26 \\
\hline \multicolumn{5}{|c|}{ SUBTOTAL } & 1,06 & 16,91 & 11,46 & 29,42 \\
\hline
\end{tabular}




\begin{tabular}{|c|c|c|c|c|c|c|c|c|}
\hline No & No & Nama Spesies & Nama Lokal & Suku & $\begin{array}{l}\text { DR } \\
(\%)\end{array}$ & $\begin{array}{l}\text { FR } \\
(\%)\end{array}$ & $\begin{array}{l}\text { DoR } \\
(\%)\end{array}$ & $\begin{array}{l}\text { INP } \\
(\%)\end{array}$ \\
\hline 37 & 1 & Anisomeles indica & - & Lamiaceae & 0,14 & 0,48 & & 0,62 \\
\hline 38 & 2 & Ardisia humilis & Lempeni & Primulaceae & 0,26 & 0,48 & & 0,74 \\
\hline 39 & 3 & Calotropis gigantea & Widuri & Apocynaceae & 14,28 & 9,66 & & 23,95 \\
\hline 40 & 4 & Chromolaena odorata & Kirinyuh & Asteraceae & 22,46 & 9,66 & & 32,12 \\
\hline 41 & 5 & Datura metel & Kecubung & Solanaceae & 0,38 & 0,48 & & 0,86 \\
\hline 42 & 6 & Indigofera $s p$. & Indigofera & Fabaceae & 3,74 & 0,48 & & 4,22 \\
\hline 43 & 7 & Ipomoea carnea & $\begin{array}{l}\text { Kangkung } \\
\text { pagar }\end{array}$ & Convolvulaceae & 7,35 & 4,83 & & 12,18 \\
\hline 44 & 8 & Jatropha gossypiifolia & Jarak merah & Euphorbiaceae & 3,33 & 2,42 & & 5,75 \\
\hline 45 & 9 & Lantana camara & Tembelekan & Verbenaceae & 11,04 & 7,73 & & 18,77 \\
\hline 46 & 10 & Pandanus tectorius & Pandan & Pandanaceae & 0,21 & 0,48 & & 0,69 \\
\hline 47 & 11 & Piper aduncum & Sirihan & Piperaceae & 0,14 & 0,97 & & 1,10 \\
\hline 48 & 12 & Solanum $s p$ & $\begin{array}{l}\text { Terong hutan } \\
\text { duri }\end{array}$ & Solanaceae & 1,00 & 1,93 & & 2,93 \\
\hline 49 & 13 & Solanum torvum & Tekokak & Solanaceaea & 1,31 & 2,42 & & 3,73 \\
\hline 50 & 14 & Vachellia farnesiana & Akasia duri & Fabaceae & 1,60 & 5,31 & & 6,91 \\
\hline 51 & 15 & Vitex pinnata & Laban & Lamiaceaea & 0,14 & 1,45 & & 1,59 \\
\hline \multicolumn{5}{|c|}{ SUBTOTAL } & 67,36 & 48,79 & & 116,15 \\
\hline \multicolumn{9}{|c|}{ Growthform Paku } \\
\hline 52 & 1 & Acrosthicum aureum & Paku laut & Pteridaceae & 1,73 & 3,38 & & 5,12 \\
\hline \multicolumn{5}{|c|}{ SUBTOTAL } & 1,73 & $\mathbf{3 , 3 8}$ & & 5,12 \\
\hline \multicolumn{9}{|c|}{ Growthform Herba } \\
\hline 53 & 1 & Colocasia esculenta & Keladi & Araceae & 0,35 & 0,97 & & 1,31 \\
\hline 54 & 2 & $\begin{array}{l}\text { Mesosphaerum } \\
\text { suaveolens }\end{array}$ & - & Lamiaceae & 0,12 & 0,48 & & 0,60 \\
\hline 55 & 3 & $\begin{array}{l}\text { Stachytarpheta } \\
\text { jamaicensis }\end{array}$ & $\begin{array}{l}\text { Jarong, Pecut } \\
\text { kuda }\end{array}$ & Lamiaceae & 12,40 & 5,80 & & 18,20 \\
\hline 56 & 4 & Typha angustifolia & Ekor kucing & Typhaceae & 15,84 & 3,38 & & 19,22 \\
\hline \multicolumn{5}{|c|}{ SUBTOTAL } & 28,70 & 10,63 & & $\mathbf{3 9 , 3 3}$ \\
\hline TO' & AL & & & & 100,00 & 100,00 & 100,00 & 300,00 \\
\hline
\end{tabular}

\section{Lampiran 2. Data parameter vegetasi lantai (understorey) di Sungai Unda, Klungkung, Bali}

Keterangan:

DR = Densitas Relatif; FR = Frekuensi Relatif; INP = Indeks Nilai Penting

\begin{tabular}{|c|c|c|c|c|c|c|c|}
\hline No & No & Nama Spesies & Nama Lokal & Suku & $\begin{array}{l}\text { DR } \\
(\%)\end{array}$ & $\begin{array}{l}\text { FR } \\
(\%)\end{array}$ & $\begin{array}{l}\text { INP } \\
(\%)\end{array}$ \\
\hline \multicolumn{8}{|c|}{ Growthform Semai } \\
\hline 1 & 1 & $\begin{array}{l}\text { Acacia } \\
\text { auriculiformis }\end{array}$ & Akasia & Fabaceae & 0,01 & 0,27 & 0,29 \\
\hline 2 & 2 & $\begin{array}{l}\text { Calophyllum } \\
\text { inophyllum }\end{array}$ & Nyamplung & Calophyllaceae & 0,69 & 0,55 & 1,24 \\
\hline 3 & 3 & Ficus septica & Awar-awar & Moraceae & 0,01 & 0,27 & 0,29 \\
\hline 4 & 4 & Lagerstroemia india & Bungur & Lythraceae & 0,02 & 0,27 & 0,30 \\
\hline 5 & 5 & $\begin{array}{l}\text { Leucaena } \\
\text { leucocephala }\end{array}$ & Lamtoro & Fabaceae & 0,04 & 0,27 & 0,31 \\
\hline 6 & 6 & Terminalia catappa & Ketapang & Combretaceae & 0,01 & 0,27 & 0,29 \\
\hline \multicolumn{5}{|c|}{ SUBTOTAL } & 0,79 & 1,92 & 2,71 \\
\hline \multicolumn{8}{|c|}{ Growthform Semak } \\
\hline 7 & 1 & Aeschynomene sp & - & Fabaceae & 0,75 & 0,27 & 1,03 \\
\hline 8 & 2 & $\begin{array}{l}\text { Alysicarpus } \\
\text { vaginalis }\end{array}$ & - & Fabaceae & 0,42 & 1,10 & 1,52 \\
\hline 9 & 3 & Ardisia humilis & Lempeni & Apocynaceae & 0,08 & 0,55 & 0,63 \\
\hline 10 & 4 & Calotropis gigantea & Widuri & Asclepiadaceae & 0,07 & 1,10 & 1,17 \\
\hline
\end{tabular}




\begin{tabular}{|c|c|c|c|c|c|c|c|}
\hline No & No & Nama Spesies & Nama Lokal & Suku & $\begin{array}{l}\text { DR } \\
(\%)\end{array}$ & $\begin{array}{l}\text { FR } \\
(\%)\end{array}$ & $\begin{array}{l}\text { INP } \\
(\%)\end{array}$ \\
\hline 11 & 5 & $\begin{array}{l}\text { Chromolaena } \\
\text { odorata }\end{array}$ & Kirinyuh & Asteraceae & 1,06 & 2,20 & 3,26 \\
\hline 12 & 6 & Crotalaria pallida & - & Fabaceae & 0,04 & 0,82 & 0,86 \\
\hline 13 & 7 & Crotalaria retusa & - & Fabaceae & 0,04 & 0,55 & 0,59 \\
\hline 14 & 8 & Croton glandulosus & - & Euphorbiaceae & 0,66 & 2,20 & 2,85 \\
\hline 15 & 9 & $\begin{array}{l}\text { Desmodium } \\
\text { rhytidophyllum }\end{array}$ & Bajang-bajang & Fabaceae & 0,13 & 1,37 & 1,50 \\
\hline 16 & 10 & $\begin{array}{l}\text { Desmodium } \\
\text { triflorum }\end{array}$ & - & Fabaceae & 6,17 & 3,85 & 10,01 \\
\hline 17 & 11 & Ficus montana & Uyah-uyah & Moraceae & 0,01 & 0,27 & 0,29 \\
\hline 18 & 12 & Indigofera $s p(2)$ & - & Fabaceae & 0,88 & 1,65 & 2,53 \\
\hline 19 & 13 & Ipomoea carnea & $\begin{array}{l}\text { Kangkung } \\
\text { pagar }\end{array}$ & Convolvulaceae & 0,02 & 0,27 & 0,30 \\
\hline 20 & 14 & Lantana camara & Tembelekan & Verbenaceae & 0,05 & 0,82 & 0,87 \\
\hline 21 & 15 & $\begin{array}{l}\text { Macroptilium } \\
\text { atropurpureum }\end{array}$ & - & Fabaceae & 0,01 & 0,27 & 0,29 \\
\hline 22 & 16 & Mimosa invisa & Rendetan & Fabaceae & 0,01 & 0,27 & 0,29 \\
\hline 23 & 17 & Mimosa pudica & Putri malu & Fabaceae & 0,38 & 1,65 & 2,03 \\
\hline 24 & 18 & Sida rhombifolia & Sidaguri & Malvaceae & 0,38 & 1,10 & 1,48 \\
\hline 25 & 19 & Solanum sp. & - & Solanaceae & 0,08 & 0,55 & 0,63 \\
\hline 26 & 20 & Solanum sp. (2) & Terong duri & Solanaceae & 0,01 & 0,27 & 0,29 \\
\hline 27 & 21 & Solanum torvum & Takokak & Solanaceae & 0,01 & 0,27 & 0,29 \\
\hline 28 & 22 & Vachellia farnesiana & Akasia duri & Fabaceae & 0,13 & 1,65 & 1,78 \\
\hline \multirow{2}{*}{\multicolumn{5}{|c|}{$\begin{array}{l}\text { SUBTOTAL } \\
\text { Growthform Herba }\end{array}$}} & 11,40 & 23,08 & 34,48 \\
\hline \multicolumn{7}{|c|}{ Growthform Herba } & \\
\hline 29 & 1 & $\begin{array}{l}\text { Alternanthera } \\
\text { sessilis }\end{array}$ & Kremah & Amaranthaceae & 2,62 & 2,75 & 5,37 \\
\hline 30 & 2 & $\begin{array}{l}\text { Andrographis } \\
\text { paniculata }\end{array}$ & Sambiloto & Acanthaceaea & 0,32 & 0,82 & 1,15 \\
\hline 31 & 3 & Asystasia gangetica & - & & 0,01 & 0,27 & 0,29 \\
\hline 32 & 4 & Barleria sp. & - & Acanthaceae & 0,05 & 0,27 & 0,32 \\
\hline 33 & 5 & Centipeda $s p$ & - & Asteraceae & 0,67 & 0,27 & 0,94 \\
\hline 34 & 6 & Colocasia esculenta & Keladi, talas & Araceae & 0,05 & 0,55 & 0,60 \\
\hline 35 & 7 & Croton hirtus & - & Euphorbiaceae & 0,11 & 0,82 & 0,93 \\
\hline 36 & 8 & Eclipta prostrata & Urang aring & Asteraceae & 0,21 & 0,55 & 0,76 \\
\hline 37 & 9 & Eichhornia crassipes & Eceng gondok & Commelinales & 0,97 & 1,92 & 2,89 \\
\hline 38 & 10 & Emilia sonchifolia & $\begin{array}{l}\text { Tempuh } \\
\text { wiyang }\end{array}$ & Asteraceae & 0,05 & 0,27 & 0,32 \\
\hline 39 & 11 & Euphorbia hirta & Patikan kebo & Euphorbiaceae & 0,80 & 3,02 & 3,82 \\
\hline 40 & 12 & Gomphrena serrata & - & Amaranthaceae & 0,61 & 0,55 & 1,16 \\
\hline 41 & 13 & Gomphrena sp. & - & Amaranthaceae & 0,10 & 0,27 & 0,37 \\
\hline 42 & 14 & Hedyotis verticillata & - & Rubiaceae & 0,25 & 0,82 & 1,07 \\
\hline 43 & 15 & Hydrolea zeylanica & - & Hydroleaceae & 0,08 & 0,27 & 0,36 \\
\hline 44 & 16 & Hyptis capitata & - & Lamiaceae & 0,06 & 0,55 & 0,61 \\
\hline 45 & 17 & Ipomoea aquatica & Kangkung & Convolvulaceae & 0,06 & 0,55 & 0,61 \\
\hline 46 & 18 & $\begin{array}{l}\text { Leucas } \\
\text { lavandulifolia }\end{array}$ & - & Lamiaceae & 0,27 & 1,37 & 1,65 \\
\hline 47 & 19 & Limnocharis flava & Genjer & Alismataceae & 0,02 & 0,55 & 0,57 \\
\hline 48 & 20 & Lindernia antipoda & - & Linderniaceae & 0,10 & 0,55 & 0,64 \\
\hline 49 & 21 & Lindernia crustacea & - & Linderniaceae & 0,29 & 1,65 & 1,93 \\
\hline 50 & 22 & $\begin{array}{l}\text { Ludwigia } \\
\text { adscendens }\end{array}$ & - & Onagraceae & 0,30 & 1,37 & 1,67 \\
\hline 51 & 23 & Ludwigia octovalvis & - & Onagraceae & 0,17 & 0,55 & 0,72 \\
\hline 52 & 24 & $\begin{array}{l}\text { Mesosphaerum } \\
\text { suaveolens }\end{array}$ & - & Lamiaceae & 0,07 & 0,27 & 0,35 \\
\hline
\end{tabular}




\begin{tabular}{|c|c|c|c|c|c|c|c|}
\hline No & No & Nama Spesies & Nama Lokal & Suku & $\begin{array}{l}\text { DR } \\
(\%)\end{array}$ & $\begin{array}{l}\text { FR } \\
(\%)\end{array}$ & $\begin{array}{l}\text { INP } \\
(\%)\end{array}$ \\
\hline 53 & 25 & $\begin{array}{l}\text { Monochoria } \\
\text { vaginalis }\end{array}$ & Enceng & Pontederiaceae & 0,13 & 0,82 & 0,96 \\
\hline 54 & 26 & Ocimum sp. & - & Lamiaceae & 0,12 & 0,55 & 0,67 \\
\hline 55 & 27 & $\begin{array}{l}\text { Oldenlandia } \\
\text { corymbosa }\end{array}$ & $\begin{array}{l}\text { Rumput } \\
\text { mutiara }\end{array}$ & Rubiaceae & 0,91 & 3,30 & 4,20 \\
\hline 56 & 28 & Phyllanthus niruri & - & Phyllanthaceae & 0,29 & 0,82 & 1,11 \\
\hline 57 & 29 & Phyllanthus sp. & - & Phyllanthaceae & 0,04 & 0,55 & 0,59 \\
\hline 58 & 30 & $\begin{array}{l}\text { Richardia } \\
\text { brasiliensis }\end{array}$ & - & Rubiaceae & 0,55 & 1,65 & 2,20 \\
\hline 59 & 31 & Solanum sp. & - & Solanaceae & 0,05 & 0,82 & 0,87 \\
\hline 60 & 32 & Spermacoce laevis & - & Rubiaceae & 0,04 & 0,27 & 0,31 \\
\hline 61 & 33 & $\begin{array}{l}\text { Sphaeranthus } \\
\text { africanus }\end{array}$ & - & Asteraceae & 0,10 & 0,27 & 0,37 \\
\hline 62 & 34 & $\begin{array}{l}\text { Sphagneticola } \\
\text { trilobata }\end{array}$ & Wedelia & Asteraceae & 0,05 & 0,27 & 0,32 \\
\hline 63 & 35 & $\begin{array}{l}\text { Stachytarpheta } \\
\text { indica }\end{array}$ & - & Verbenaceae & 0,08 & 0,55 & 0,63 \\
\hline 64 & 36 & $\begin{array}{l}\text { Stachytarpheta } \\
\text { jamaicensis }\end{array}$ & Pecut kuda & Verbenaceae & 0,70 & 2,47 & 3,18 \\
\hline 65 & 37 & Synedrella nodiflora & Babandotan & Asteraceae & 0,05 & 0,55 & 0,60 \\
\hline 66 & 38 & $\begin{array}{l}\text { Trianthema } \\
\text { portulacastrum }\end{array}$ & - & Aizoaceae & 0,35 & 0,55 & 0,90 \\
\hline 67 & 39 & Tridax procumbens & Gletang & Asteraceae & 0,62 & 1,10 & 1,72 \\
\hline 68 & 40 & Typha angustifolia & Ekor kucing & Typhaceae & 0,24 & 0,82 & 1,06 \\
\hline & 12,52 & 36,26 & 48,78 \\
\hline \multicolumn{8}{|c|}{ Growthform Rumput } \\
\hline 69 & 1 & $\begin{array}{l}\text { Axonopus } \\
\text { compressus }\end{array}$ & - & Poaceae & 0,62 & 0,27 & 0,89 \\
\hline 70 & 2 & Chloris barbata & - & Poac eae & 0,41 & 1,10 & 1,50 \\
\hline 71 & 3 & $\begin{array}{l}\text { Chrysopogon } \\
\text { aciculatus }\end{array}$ & - & Poaceae & 1,29 & 1,10 & 2,39 \\
\hline 72 & 4 & Cynodon dactylon & Padang kawat & Poaceae & 10,33 & 3,02 & 13,35 \\
\hline 73 & 5 & Cyperus compressus & Teki & Cyperaceaea & 0,95 & 0,55 & 1,50 \\
\hline 74 & 6 & Cyperus difformis & Teki & Cyperaceae & 0,02 & 0,27 & 0,30 \\
\hline 75 & 7 & Cyperus involucratus & Teki payung & Cyperaceaea & 0,24 & 0,82 & 1,06 \\
\hline 76 & 8 & $\begin{array}{l}\text { Cyperus } \\
\text { polystachyos }\end{array}$ & Teki & Cyperaceae & 1,67 & 0,55 & 2,22 \\
\hline 77 & 9 & Cyperus rotundus & Teki & Cyperaceaea & 3,43 & 1,37 & 4,81 \\
\hline 78 & 10 & Cyperus sp. & Teki & Cyperaceaea & 0,04 & 0,27 & 0,31 \\
\hline 79 & 11 & $\begin{array}{l}\text { Dactyloctenium } \\
\text { aegyptium }\end{array}$ & - & Poaceae & 2,72 & 3,02 & 5,74 \\
\hline 80 & 12 & Digitaria longiflora & - & Poaceae & 0,99 & 1,10 & 2,09 \\
\hline 81 & 13 & Echinochloa colona & Rumput bebek & Poaceae & 0,12 & 0,27 & 0,39 \\
\hline 82 & 14 & Eleusine indica & Belulang & Poaceae & 0,55 & 1,10 & 1,65 \\
\hline 83 & 15 & Eragrostis amabilis & - & Poaceae & 1,82 & 2,20 & 4,02 \\
\hline 84 & 16 & $\begin{array}{l}\text { Eragrostis cf. } \\
\text { cilianensis }\end{array}$ & - & Poaceae & 0,10 & 0,27 & 0,37 \\
\hline 85 & 17 & Eragrostis minor & - & Poaceae & 1,94 & 0,82 & 2,77 \\
\hline 86 & 18 & Eragrostis sp. & - & Poaceae & 0,08 & 0,27 & 0,36 \\
\hline 87 & 19 & Fimbristylis miliacea & - & Cyperaceaea & 0,45 & 0,55 & 1,00 \\
\hline 88 & 20 & Ischaemuт muticum & - & Poaceae & 2,03 & 0,82 & 2,85 \\
\hline 89 & 21 & Kyllinga brevifolia & Teki & Cyperaceaea & 0,43 & 0,82 & 1,25 \\
\hline 90 & 22 & Kyllinga gracillima & Teki & Cyperaceaea & 3,91 & 3,30 & 7,21 \\
\hline 91 & 23 & Leersia hexandra & - & Poaceae & 2,91 & 0,27 & 3,18 \\
\hline 92 & 24 & Melinis repens & Rumput natal & Poaceae & 0,10 & 0,55 & 0,64 \\
\hline 93 & 25 & Murdannia nudiflora & - & Commelinaceae & 2,15 & 1,10 & 3,25 \\
\hline
\end{tabular}




\begin{tabular}{|c|c|c|c|c|c|c|c|}
\hline No & No & Nama Spesies & Nama Lokal & Suku & $\begin{array}{l}\text { DR } \\
(\%)\end{array}$ & $\begin{array}{l}\text { FR } \\
(\%)\end{array}$ & $\begin{array}{l}\text { INP } \\
(\%)\end{array}$ \\
\hline 94 & 26 & $\begin{array}{l}\text { Paspalum } \\
\text { conjugatum }\end{array}$ & - & Poaceae & 0,04 & 0,27 & 0,31 \\
\hline 95 & 27 & Paspalum dilatatum & - & Poaceae & 0,41 & 0,55 & 0,95 \\
\hline 96 & 28 & Scirpus maritimus & - & Cyperaceae & 5,93 & 1,92 & 7,85 \\
\hline 97 & 29 & Scirpus sp. & - & Cyperaceae & 1,68 & 1,37 & 3,06 \\
\hline 98 & 30 & $\begin{array}{l}\text { Urochloa } \\
\text { mosambicensis }\end{array}$ & - & Poaceae & 0,24 & 0,55 & 0,79 \\
\hline 99 & 31 & Zoysia matrella & Padang lepas & Poaceae & 27,14 & 4,67 & 31,81 \\
\hline \multicolumn{5}{|c|}{ SUBTOTAL } & 74,72 & 35,16 & $\mathbf{1 0 9 , 8 8}$ \\
\hline \multicolumn{8}{|c|}{ Growthform Paku } \\
\hline 100 & 1 & Acrosthicum aureum & Paku laut & Pteridaceae & 0,07 & 0,55 & 0,62 \\
\hline 101 & 2 & $\begin{array}{l}\text { Pityrogramma } \\
\text { calomelanos }\end{array}$ & Paku perak & Pteridaceae & 0,01 & 0,27 & 0,29 \\
\hline \multicolumn{5}{|c|}{ SUBTOTAL } & $\mathbf{0 , 0 8}$ & $\mathbf{0 , 8 2}$ & $\mathbf{0 , 9 1}$ \\
\hline \multicolumn{8}{|c|}{ Growthform Liana } \\
\hline 102 & 1 & $\begin{array}{l}\text { Centrosema } \\
\text { pubescens }\end{array}$ & - & Fabaceae & 0,16 & 1,10 & 1,25 \\
\hline 103 & 2 & Ipomoea pes-tigris & - & Convolvulaceae & 0,26 & 0,55 & 0,81 \\
\hline 104 & 3 & Mikania cordata & $\begin{array}{l}\text { Sembung } \\
\text { rambat }\end{array}$ & Asteraceae & 0,06 & 0,82 & 0,88 \\
\hline 105 & 4 & Stephania japonica & - & $\begin{array}{l}\text { Menispermacea } \\
\mathrm{e}\end{array}$ & 0,01 & 0,27 & 0,29 \\
\hline \multicolumn{5}{|c|}{ SUBTOTAL } & 0,49 & 2,75 & 3,24 \\
\hline \multicolumn{5}{|c|}{ TOTAL } & $\mathbf{1 0 0 , 0 0}$ & $\mathbf{1 0 0 , 0 0}$ & 300,00 \\
\hline
\end{tabular}

